\title{
Online Journalism and the Challenge of Ethics in Nigeria
}

\author{
Chike Walter Duru \\ Justice For All/British Council, Abuja, Nigeria
}

\begin{abstract}
Online journalism has changed the face of journalism practice in Nigeria and the world at large. The Internet has virtually revolutionized the process of news and information gathering and dissemination. However, not abiding by the ethics of the profession has become its major burden, a situation that is blamed on certain identified factors. Presently, there is no clear distinction between the role of conventional journalism and citizen journalism. Conventional journalism, which is the mainstream profession of journalism, requires one form of training or the other, either through education or on the job training, for them to discharge their social responsibility role, unlike in the case of citizen journalism, which is presently usurping the role of conventional journalism. This development spells negative effects to the trend of journalism. No doubt, the Internet has removed the barriers of space and time on human interactions; hence, information can easily be obtained at a relatively low cost; but, the major challenges are those of ethics, professionalism, and training. These issues need to be addressed urgently before they set the country on fire. This article traces the background of the ethical challenge and examines its management, highlighting the steps that could be taken to tackle the menace. The reasons for the continued growth in audience of new news site are also explained.
\end{abstract}

Keywords: online journalism, citizen journalism, conventional journalism, ethics, social responsibility

\section{Introduction}

The advent of online media across the globe is a historic revolution that has changed the fortunes of journalism practice and shaped the profession in a symbolic form. The dissemination of editorial content via the Internet is central to the practice of journalism online.

According to Wikipedia, "Digital journalism, also known as online journalism is a contemporary form of journalism where editorial content is distributed via the Internet as opposed to publishing via print or broadcast". Editorial contents, especially, news, features, analysis and editorial on current issues are disseminated through digital media platforms.

Today, readers with access to the Internet can be informed of happenings across the globe, even from the comfort of their homes. In fact, online journalism has dealt a great blow on the regular print media. Sales of print copies have dropped, with huge implications to the business fortunes of media organisations.

The Internet challenges traditional news organizations in several ways. Newspapers may lose classified advertising to websites, which are often targeted by interest instead of geography. These organizations are concerned about real and perceived loss of viewers and circulation to the Internet (Tijani, 2013). Little wonder most regular print media organisations are now investing heavily in their online versions.

Chike Walter Duru, Ph.D, Justice For All/British Council. 


\section{Historical Origin of Online Journalism}

In 1993, the University of Florida's Journalism Department launched what is generally considered to be the first online journalism web site. It was a very basic, static web site, with a picture of the red-bricked wall of the Journalism Department. It was updated only occasionally, at nights and weekends, when the machine was not in use by others, running on a 486-25 processor with 4 megabytes of random access memory (RAM).

In November 1994, The UK's Daily Telegraph launched the Electronic Telegraph, which was a similarly static page, with articles one on top of the other. The online publication followed the rhythm of print publishing, posting online contents once a day.

In a 2001 article, Derek Bishton detailed the Electronic Telegraph's remit: to explore the new medium, its technological and commercial possibilities, as well as the scope for the launch of the Telegraph as an online brand (Bishton, 2011).

Another early leader in online journalism was The News \& Observer in Raleigh, North Carolina. Steve Yelvington wrote on the Poynter Institute website about Nando, owned by The N\&O, by saying "Nando evolved into the first serious, professional news site on the World Wide Web". It originated in the early 1990s as "Nando Land".

Generally, online news sources began to proliferate in the 1990s. Salon, founded in 1995, was an early leader of online-only reporting. In 2001, the American Journalism Review called Salon the Internet's "preeminent independent venue for journalism". That was how online journalism, an innovation that has changed the face of journalism practice forever began.

Audiences for online journalism continue to grow. In 2008, for the first time, more Americans reported getting their national and international news from the Internet, rather than newspapers. Young people, aged 18 to 29 now primarily get their news via the Internet, according to a PEW Research Center report. Audiences to news sites continued to grow due to the launch of new news sites, continued investment in news online by conventional news organizations and the continued growth in Internet audiences overall.

The Online News Association, founded in 1999, is the largest organization representing online journalists, with about two thousand $(2,000)$ members whose principal livelihood involves gathering or producing news for digital presentation.

\section{Online Journalism: The Nigerian Experience}

Beginning from the establishment of Iwe Irohin in 1859, the mass media in Nigeria have not failed in the attempt to be abreast with modern technology. However, continued underdevelopment and poor governance have hampered its ability to absorb and deploy recent advances in technology. The Nigerian mass media risk being left behind unless the chain of economic stagnation is broken and a higher level of development recorded.

Prior to the era of online journalism in Nigeria, there were a number of newspapers that made a lot of impact in the country. Prominent among them were: This Day, The Guardian, The Vanguard, The Punch, Nigerian Tribune, The Nation, Daily Trust, Leadership, Daily Independent, National Mirror, Business Day, Champion, Daily Sun and recently, Blue Print, Peoples Daily, New Telegraph, The Union, Nigerian Pilot and Authority newspapers. The hard copy trend dominated the print, apparently unchallenged.

Between 2003 and 2010, there was an experiment of a strictly online newspaper in Nigeria. Among the early birds in the experiment were the likes of Sahara Reporters, Gamji.com, Elombah.com and the Nigerian Voice. At 
that time, not many saw the online evolution in Nigeria as a major threat to the regular print until later, when their impacts became obvious in various sectors of the society.

Today, the list of online newspapers in Nigeria is endless. Prominent among them, in addition to the earlier listed are: Premium Times, Naij.com, The Cable, The Agenda (Agendang.com), Atlantic Reporters, Daily Post, Breaking Times, Eagle Online, Osun Defender, Sweet Crude Reports, Linda Ikeji blog, The Pulse, Information Nigeria, Olufamous.com, YNaija.com, Signal Nigeria, Nigerian Eye and Naija gists.

Others include: The Trent, Today Nigeria, Encomium Nigeria, Ventures Africa, Nigerian Finder, My School Gist, Net Media, Spread Media, Naija Parrot, Omojuwa.com, 247 u-Reports, Cyber Naira, among others. In fact, the fear of online newspapers is the beginning of wisdom in public offices in today's Nigeria. They have made information dissemination easy and checked the monopoly of media owners in the country; that is, it is no longer easy for a hand full of major media owners to decide to either stifle or distort reports. In fact, as they try to manage information in public institutions, online newspapers assist to blow up such reports. This has in no small measure, assisted whistle blowing in the country and served as a check on the activities of public office holders.

\section{Advantages of Online Publications}

No doubt, the Internet is the greatest communication invention of man in recent times. This is mostly as a result of the convergence power which it has, and which has also been used to bring other traditional media to a common plane (Chile, 2015). The benefits of online publications are enormous. They include:

- Timely release of reports;

- Free to access;

- Interactive and allows for immediate feedback;

- Requires little capital to set up;

- Requires fewer personnel.

\section{Disadvantages of Online Newspapers}

Despite the excitement that has heralded the advent of online media, it has its own baggage. They include:

- Absence of Internet facilities/technology in some localities;

- Ethical/professional challenges;

- The usual challenge of navigating the world wide web;

- Faceless and have no verifiably physical office address, with many operating as illegal entities.

\section{Online Media vs Traditional Print Media}

When the Internet came into being, newspaper managers were confused as to the right approach towards its usage (Jones \& Salter, 2012, p. 37). Their first reaction was to export their entire information on the web through a measure known as shovelware (Jones \& Salter, 2012, p. 45). That was the first tactical error by the newspapers (Gunter, 2003, p. 166). News consumers got accustomed to free news; hence attempts to introduce pay walls (Greer \& Mensing, 2006, p. 18) thereafter by the newspapers were resisted.

More so, the emergence of news aggregators and online advertising platforms such as Google, Twitter, Linkedin, Facebook, Graigslist, Monster.com, Yahoo, among others, robbed the newspapers of not only their readers but also revenues (Jones \& Salter, 2012, pp. 20-22). The development compelled newspaper owners to search for appropriate business models for survival. Rodman (2009, p. 37) explains that the presence of goggle news, twitter, facebook and other social networking media are also changing the phase of journalism. 
Print businesses across the world, especially, newspapers are facing many challenges. These are brought about by the challenges of the changing times, changes in socio-cultural traits in different societies, demographic changes which inform new audience taste for news, economic challenges, as well as the impact of new technologies (Smith, 1980; Jones \& Salter, 2012). These challenges have, no doubt, denied them readership and revenue. The emergence of the Internet and new media technology is disrupting the economic base of the newspapers, as many potential readers are finding alternative sources of news online (Daily Trust, 2012; Jones \& Salter, 2012, p. 37).

Some scholars have however argued that this development is limited to only a part of the world, particularly the United Kingdom and the United States of America, with newspapers in Asia and Africa said to be enjoying a boom (Franklin, 2009).

In Nigeria, the face of the newspapers can be said to be changing greatly. The advent of online newspapers, as well as other new media poses a major challenge to the old-styled hard copy pattern of conventional media; a development that compelled them to evolve in order to remain afloat. Today, they have embraced the trend and taken their online platforms more seriously. The Nigerian newspapers can now be read on the Internet just like the London Times, New York Times, Le Monde of France and others. The challenge posed by strictly online newspapers and social media platforms have kept newspapers on their toes, thereby compelling them to move with the tide.

The Internet challenges traditional news organizations in several ways. Newspapers may lose classified advertising to websites, which are often targeted by interest instead of geography. These organizations are concerned about real and perceived loss of viewers and circulation to the Internet (Folashade, 2013).

\section{Ethical Issues in Online Journalism Practice in Nigeria}

Ethics are important in journalism practice because they prescribe acceptable codes of professional behaviour. The birth of online media has with it an ethical challenge that calls for attention. Just as Gutenberg made everyone a printer with the invention of printing press, the advent of Internet has practically made everyone a journalist. Citizen journalism has made it a reality for everybody to be media creator, owner and actor, instead of passive user (Ezeibe \& Nwagwu, 2009, pp. 65-66). They further add that citizen journalism gradually debases the conventional journalism, hence, information role that professional journalism does dissolves into public domain. Some of the ethical issues are discussed below:

\section{Accuracy}

Over the years, questions have arisen over the degree of accuracy of reports published online, with many established as untrue. A lot of online platforms are mere rumour mills and do not bother to verify facts before going to press. Despite attempts of the online news outlets to break stories, there is still scepticism about the quality of journalism produced on the Internet. That scepticism could explain the continued resistance of the traditional media to acknowledge stories sourced from the Internet.

A lot of the emerging managers of online news organisations do not have adequate journalistic training, compared to those in the traditional media. Some of them are quick to break stories in order to increase traffic, enhance their market positioning and increase popularity; but do not pay attention to following a rigorous editorial procedure, aimed at ensuring accuracy. 


\section{Plagiarism}

The obvious lack of acknowledgement of sources and sometimes outright plagiarism is a major challenge in online journalism practice in Nigeria. The ethics of the profession demand that all sources of information be attributed. Attribution enhances the credibility of the medium and protects it from falling into legal disputes, should the story be a fabrication or contains libel or defamation. Today, online platform will curl reports from other sources and refuse to give credit to such sources.

\section{Obscenity}

Obscenity suggests any utterance or act that strongly offends morality. Publishing of pornography, nudity and sexual violence is a typical example of obscenity. Before now, it was a taboo in journalism practice, but, today, it is prevalent in online journalism and the society does not see anything wrong with it anymore. Daily, materials offensive to the public sense of decency are published online, contrary to ethical demands and expectations.

\section{Reporting on Children and Minor}

This is very worrisome. Ethically, a journalist is not allowed to identify, either by name or picture, or interview children under the age of 16 who are involved in cases relating to sexual offences, crimes and rituals or witchcraft, irrespective of whether they are victims, witnesses or defendants. Today, images and names of minors are celebrated online, not minding the implications of such on the lives and future of the affected children.

\section{Decency}

Apart from dressing in a manner that conforms to public taste, ethics prohibit the use of offensive, vulgar and abusive language by a journalist. He/she is also not permitted to present vivid details, either in words or pictures, of violence, sexual acts and horrid scenes. Today, these things are also celebrated online. In fact, such indecent materials are hyped as a way of attracting more traffic to such news websites.

\section{Why Are the Ethics not Complied With?}

\section{Poor Training}

A lot of the emerging online news organisations do not have adequate journalistic training, compared to those in the traditional media. This does not in any way exonerate traditional media practitioners from culpability in unethical practices. Most of them are as guilty as the former.

For the traditional media practitioners themselves, the quality of training is also a source of worry. The institutions that train the journalists, from polytechnics to universities suffer from shortage of the basic infrastructure required to train future journalists. What about their course contents? Most of them do not address contemporary issues in the journalism profession.

\section{Academic Curriculum}

The imbalance between academics who teach journalism and professionals from the industry who train the students on "the field experience" is so wide, to the extent that when students graduate from the college or university, they are not ready to go into practice, rather, their new employers have to retrain them, before they are then ready to function as proper journalists (Yusha'u, 2013). A situation where academics that do not have any form of field experience are assigned to teach practical courses in the profession is not helpful. 


\section{Job Satisfaction and Passion}

Journalism is a profession that goes with passion. For someone who just joined the profession because of unavailability of jobs, whatever comes his/her way is sent to newsroom. This has ridiculed the media profession, with most people claiming to be talented writers. Journalism is a profession and whoever wants to practise it needs to be trained for same.

\section{Government Response}

\section{Anti-Social Media Bill 2015}

Attempts to gag the press in Nigeria, even under military regimes, met with stern resistance; and only succeeded in pitching government against the people and the press, and creating social unrest.

Notwithstanding the enactment of the Cyber Act in 2015, a "Bill for an Act to Prohibit Frivolous Petitions and other matters Connected Therewith, 2015 (SB.143)", within eight days, reportedly, passed through second reading in the Nigerian Senate. The bill targets on-line media platforms such as Facebook, Twitter, Instagram, YouTube, Whatsapp, on-line blogs and the like, believed to be growing exponentially.

The Guardian newspaper of December 15, 2015 quoted Senator Bala Ibn Na'Allah, Deputy Senate Leader, who sponsored the bill, as saying the aim was to bring sanity into the system and make way for "credible and verifiable" petitions.

The bill provides inter alia: "Where any person in order to circumvent this law makes any allegation and or publishes any statement, petition in any paper, radio, or any medium of whatever description, with malicious intent to discredit or set the public against any person or group of persons, institutions of government, he shall be guilty of an offence and upon conviction, shall be liable to an imprisonment term of two years or a fine of N4 million".

Reacting to the bill, Civil Society organisations under the aegis of Freedom of Information Coalition in Nigeria described the move as draconian and aimed at gagging the press; even as they threated to embark on a one million man march on the streets of Abuja in protest.

In a Press statement captioned: "Reject Anti-Social Media Bill, FOI Coalition Tells Stakeholders", signed by its Chairman, Board of Governors, Dr. Walter Duru, the group further described it as irresponsible, warning that it would spell doom for the country's democracy.

Following public outcry, the Senate withdrew the bill and allowed the statuesque to remain.

\section{The Cybercrimes Act 2014}

One of Nigeria's first attempts to criminalize Cybercrimes was in 1995. The draft legislation of the Electronic Crimes, Telecommunications and Postal Offences Decree of 1995 defined Cybercrime as "...engaging in computer fraud or does anything to fake payments, whether or not the payment is credited to the account of an operator or the account of the subscriber, is guilty of an offence". This was the precursor to several legislations that were to shape contemporary activities on the Internet in Nigeria.

Nigeria recorded a fair attention to its cybercrime environment upon her transition to democracy in May, 1999. This helped the government reposition its core mandates and battling cybercrimes became one of these objectives. This saw to drafting and review of draft legislations which includes but not limited to the Computer Security and Infrastructure Bill of 2005, Electronic Provisions Bill of 2008, Cyber-security Bill of 2011, Criminal Code Amendment for Offences Relating to Computer Misuse and Cybercrimes of 2011, Electronic Transfer of Funds Crime Bill of 2001. Most of these Bills were either dropped due to lack of government 
sincerity of purpose or due to the inability of the Nigerian government to stay committed to the socio-legal growth of its citizens (Ilori, 2015).

In July 2011, a Bill which is known today to be the Cybercrimes (Prohibition, Prevention, ETC) Act was introduced to the Nigerian parliament by the then Executive arm of government. The Bill was finally passed into law on the 23rd of October, 2014. This marked the beginning of an era which defined all cyber activities in Nigeria.

\section{Conclusion}

There is no gainsaying the fact that online journalism has changed the face of media practise in Nigeria. It has given a voice to Nigerians and enhanced citizens' journalism. Whistle blowing, aimed at exposing the rot in our society has also flourished, courtesy of online journalism practise. Indeed, online journalism and the accompanying technology are blessings to the Nigerian society and have helped in consolidating Nigeria's democracy. The convergence of computer and telecommunications are the material forces in the new technology of mass communication (Yusha'u, 2013).

Nwajinka (2003, p. 118) contends that journalists in the digital age have no excuse but to make use of online libraries to enrich their performance. However, flagrant disregard to ethical expectations and demand constitute its greatest burden. From respect for people's privacy, to accuracy and fairness, non-disclosure, decency and violence, most online media practitioners are found wanting. Most the tilt of stories is informed by economic, personal or political interests; at the expense of ethical demands of objectivity, fairness, accuracy and balance. Impunity and blackmail flourish. The rights of citizens are abused daily. Not even the coming together of some of the online groups has addressed the issue. Worthy of note is that two groups: Guild of Corporate Online Publishers (COCOP) and Online Publishers Association of Nigeria (OPAN) were formed, partly with a view to self-regulate online practise; but a lot of the publishers do not belong to either of the groups. Online publishing is today, an all-comers affair. Social Responsibility is hardly considered in online journalism. Just like most of their traditional media counterparts, reward and gratification is a culture. Brown envelope syndrome appears to have come to stay permanently in the industry. The unethical practices are gradually derailing the process, at the expense developmental journalism. Most of the newspapers have no verifiable physical office addresses, while the names of the actual proprietors and publishers are also unknown, contrary to existing laws. The challenge is to do a good job in informing and educating the Nigerian public. There is no doubt that the online journalism industry in Nigeria is growing rapidly. Many people, especially the youth are now showing keen interest in participatory journalism. The major challenge is that of ensuring that the sacred ethics of the journalism profession remain sacrosanct. Unless something is done urgently, online journalism may set the country on fire someday.

\section{Recommendations}

In view of the foregoing, the following suggestions would be helpful.

(1) One question that is yet to be answered satisfactorily in Nigeria is that of whom a Journalist is. So, who is a Journalist and what are the qualifications for the practise of journalism in Nigeria? Just as no one can practise Law or Medicine without being trained, no one should practise journalism unless he/she is properly trained and qualified. Be it for online or traditional media, no one should be in the business of journalism without requisite qualification. 
(2) The Nigerian Press Council should be strengthened; competent leadership entrenched and its mandate expanded to include regulation of online media. Strengthening of its mandate is necessary, as, the Council; as is presently constituted is a toothless bull dog and cannot really bite substantially. The legal framework needs to be strengthened and vibrant leadership entrenched.

(3) Self-regulation is a sure way forward. Online publishers must come together and agree on some operational, ethical and professional issues. Coming together under one umbrella will be helpful, as certain guiding rules are expected to be introduced on professional practise.

(4) Journalism institutions should introduce courses in online journalism in their faculties and departments. This is to allow would-be journalists to become intelligently grounded in the practise in ways that are transformative. The need to also review the academic curriculum in the communication departments and faculties of Nigeria's Institutions of higher learning cannot be over emphasized. This is with a view to addressing the obvious knowledge and competence gaps in training of Nigerian Journalists and other communication professionals.

(5) Media practitioners (Reporters, Correspondents and Editors) should undertake intensive and continuous on-the-job training in online journalism, while intending journalists should be encouraged to obtain relevant professional qualifications to practise journalism.

(6) Online media practitioners should avail themselves the opportunity of training and retraining, especially, in the area of responsible and professional journalism. Majority of the conflicts in the country today were escalated by the media. The media owes the citizens a debt- "social responsibility". That must therefore propel them for regular training and retraining. The media can bring peace and create wars. "Peace educators should dedicate more time, energy and commitment to peace reporting and peace education in order to provide the public, scholars and practitioners with the information they need to participate in the peace process" (Ersoy, 2006).

(7) Online media practitioners must be better informed than the public they seek to serve. An uninformed or a poorly-informed Journalist is like a dangerous animal unleashed on the people. Today, what often passes for exclusive stories are fiction dressed as facts in the press; a development that is not helpful to the Nigerian society. They must also sharpen their editorial judgement.

(8) The Nigerian Union of Journalists, NUJ, has an important role to play. They must revisit the code of conduct of the Nigerian media, and devise some other ways to address the ethical challenges facing the media profession.

(9) Media houses should create partnership among themselves; the news organisations that publish purely on online platforms, and the traditional ones that produce both hardcopies and publish online versions, can easily exchange stories, train staff, use the by lines of reporters, and even share offices in the areas where only one of the partners has a bureau. This could go a long way in addressing issues of plagiarism, originality and ethics.

\section{References}

Aliagan, I. Z. (2015). Examining survival strategies employed by Nigerian Newspapers against loss of readership and revenues. Journal of New Media and Mass Communication, 35(9), 451.

Batta, H. E. (2009). Peace education, peace journalism, and conflict management in Nigeria. The Nigerian Journal of Communication, 7(1), 159-183.

Bishton, D. (2011). The evolution of online journalism. The Handbook of Global Online Journalism, 9(3), 55. 
Chile, S. T. (2015). Readers' perception of Nigerian newspapers on the Internet. Journal of Philosophy, Culture and Religion, 4 , 26-34.

Daily Trust. (2012). Kaduna newspaper vendors say online publication disrupts sales. Daily Trust.

Ersoy, M. (2006). Peace Journalism and Traditional Journalism (p. 20). Cyprus newspaper, newspaper article.

Ezeibe, C. C., \& Nwagwu, E. J. (2009). Media imperialism and crisis of development. International Journal of Communication, 10, 65-66.

Folashade, T. (2013). Online Journalism. Retrieved from http://kissfola.blogspot.com.ng/2013/02/online-journalism.html

Franklin, B. (2009). Evidence gathering on the current state of the Welsh Newspaper Industry-The future of newspapers: A comparative assessment. Broadcasting Sub-Committee: 5 March.

Greer, J. D., \& Mensing, D. (2006). The evolution of online newspapers: A longitudinal content analysis, 1997-2003. In L. Xigen (Ed.), Internet Newspapers: The Making of a Mainstream Medium. London: Lawrence Associates Publishers.

Griffin, E. (2000). A first look at communication theory (4th ed). Boston, Ma: McGraw-Hill.

Gunter, B. (2003). News and the Net. London: Lawrence Associates Publishers.

Ilori, T. (2015). The Nigerian Cybercrimes Act 2015: Is It Uhuru Yet? Retrieved from $\mathrm{http}: / / w w w . o r d e r p a p e r . n g /$ nigerian-cybercrimes-act-2015-uhuru-yet

Jones, J., \& Salter, L. (2012). Digital Journalism. Los Angeles: Sage Publications Ltd.

Nwajinka, C. O. (2003). Information and communication technology in Nigeria. In O. Uwakwe (Ed.), Communication and National Development. Onitsha: Afrika-Link Books.

Rodman, G. (2009). In a changing world-History industry controversy (3rd ed.). New York: McGraw Hill.

Smith, W. (1980). Challenges of print business: In Isiaka, Z. A. examining survival strategies employed by Nigerian newspapers against loss of readership and revenues. Journal of New Media and Mass Communication, 35(9), 9.

Talabi, F. O. (2011). The Internet and Journalism practice in Nigeria. Global Journal of Human Social Science, 11(10), 48.

The Guardian. (2015). The anti social media bill. Wikipedia.

Tijani, F. (2013). Online Journalism in Nigeria. Retrieved from http://kissfola.blogspot.com.ng/

Yusha'u, M. J. (2013). Online journalism and the ethical question in the Nigerian media. Retrieved from $\mathrm{http}$ //www.premiumtimesng.com/opinion/152326-focus-85-online-journalism-ethical-question-nigerian-media-ii-muhamma d-jameel-yushau.html 